\title{
Physical Activity and Leisure in the Daily Life of Nursing Students
}

\author{
Letícia Yamawaka de Almeida ${ }^{(0)}$, Jaqueline Lemos de Oliveira $\mathbb{D}^{\circ}$, \\ Janaína Cristina Pasquini de Almeida ${ }^{\circledR}$, Aline Cristina Dadalte ${ }^{\circledR}$, Samuel Barroso Rodrigues $\mathbb{D}^{\circ}$, \\ Camila Maria Fernandes Fantacini $\left(\mathbb{D}\right.$, Ricardo Henrique Guandolini ${ }^{\circ}$, Jacqueline de Souza ${ }^{(1)}$
}

Psychiatric Nursing and Human Sciences Department, Ribeirão Preto College of Nursing, University of São Paulo, Ribeirão Preto, Brazil

Email: jaquelemos@usp.br

How to cite this paper: de Almeida, L.Y., de Oliveira, J.L., de Almeida, J.C.P., Dadalte, A.C., Rodrigues, S.B., Fantacini, C.M.F., Guandolini, R.H. and de Souza, J. (2020) Physical Activity and Leisure in the Daily Life of Nursing Students. Open Journal of Nursing, 10, 918-928.

https://doi.org/10.4236/ojn.2020.109063

Received: August 25, 2020

Accepted: September 24, 2020

Published: September 27, 2020

Copyright $\odot 2020$ by author(s) and Scientific Research Publishing Inc. This work is licensed under the Creative Commons Attribution International License (CC BY 4.0).

http://creativecommons.org/licenses/by/4.0/ (c) (i) Open Access

\begin{abstract}
The aim of this paper was to describe the routine of Brazilian nursing students, identifying the activities that are part of their daily life, highlighting how much time they dedicate for physical activity practice in their leisure time. The participants of this cross-sectional study were 141 nursing students from a public university in the State of São Paulo. Data were collected using a sociodemographic questionnaire, three closed questions about physical activities and one open question in which the students described their daily life activities. For analysis, we used the chi-squared-test and content analysis. Although academic, household and work activities take up most of the students' week, some dedicate a portion of their daily live to enjoy leisure periods with physical activities, sedentary behavior and sociocultural activities. Some options of activities seem to be related to Brazilian cultural aspects that are pointed out in this paper. Some recommendations were made, aiming at improving the health of students as well as the importance of a healthier school environment.
\end{abstract}

\section{Keywords}

Leisure, Physical Activities, Mental Health, Nursing Students

\section{Introduction}

The routine of university students has been the focus of studies related to leisure, subjective well-being, health maintenance and promotion [1] [2] [3]. These studies show that, although university students use most of their time for academic activities, they also engage in cultural, artistic, religious, touristic and social ac- 
tivities [4]-[14].

Studies reveal that occupations diversification has been beneficial for improving life satisfaction [13] [14] and mental health [10] [11] [15]. On the other hand, the shortage of occupations dedicated for leisure may result in damage of the quality of life and negatively influence the students' well-being, being a triggering factor of negative feelings [15] [16].

In this sense, considering the usual dynamics of university students, it is understood that the occupations of free choice are often not privileged, which can result in possible oscillations of the quality of life and health [15] [17] [18].

Concerning specifically the health sciences course, practical training may contribute to increase tension, strain, stress, fatigue, and psychological suffering levels [15] [17] [18] [19]. Therefore, prioritizing healthy activities in the leisure time is an important factor to be considered in the set of strategies for health promotion.

Among leisure possibilities, physical activity (PA) has been described as an important factor related to students' health promotion. Despite the known benefits, some studies have shown that university students devote short time for such activities as a leisure option [4] [8] [9] [10] [12] [14].

Recent studies on PA and leisure among students has investigated both the population of university students in general [4] [5] [6] [7] [14] [20], as well as students from specific courses such as physical education [13], medicine [9], and nursing [21]. The main focus of these studies has been the influence of such activities in life satisfaction and mental health of this population, highlighting specific characteristics related to the routine of each course. However, there is a gap in exploring how physical and leisure activities are allocated in these students' routine set of occupations and what are the free choice possibilities that these students have listed in their daily lives. Thus, this study aims to describe the routine of Brazilian nursing students, identifying the activities that are part of their daily life, highlighting how much time they dedicate for PA practice in their leisure time.

It is appreciated that investigations aimed at identifying the occupations related to PA and leisure among university students are of great importance because they may improve the discussions for strategy development in the academic and other care settings that contribute for positive results both in their health and performance.

\section{Methods}

\subsection{Study Participants, Setting, and Sampling}

This descriptive cross-sectional study was developed in a university campus from São Paulo, Brazil. This campus had around 570 nursing students. Our eligibility criteria were: being regularly enrolled, being 18 years or older and presenting motor skills and visual acuity that allowed participants to fill in the questionnaire. Participants were recruited in person in the classrooms before the begin- 
ning of class or during breaks, $80 \%$ of which met the eligibility criteria, and the sample size was calculated considering a 95\% confidence level and $7 \%$ margin of error. The number of students necessary for the sample size according to this calculation was 138, and 141 students participated in our investigation.

\subsection{Measures, Data Collection, and Data Analysis}

The aim of this study and the ethical aspects were explained, and the participants were invited to fill in a sociodemographic questionnaire, to answer three questions about PA (modality, frequency, and if they knew of any free PA programs), and an open question about activities carried out in their daily lives. Data were analyzed using descriptive analyses, chi-squared test and odds ratio calculation. We used content analysis to interpretation of the open question data.

\subsection{Ethical Considerations}

This study was elaborated according to the guidelines of CNS Resolution 466/12 for the development of research with human beings. It was submitted and approved by the Research Ethics Committee of the university-protocol 18937813.5.00005393. To maintain the anonymity of the participants, the students were identified with the code "EST" and the corresponding number of the questionnaire filled in.

\section{Results}

The majority of the participants were female, aged between 18 and 20 years old, considered themselves white and had a household income under five minimum wages (Table 1).

A total of $43.9 \%$ (62) participants took part in some type of PA. The frequency and modality of PA mentioned by students and the number of them that affirmed to know of any free PA programs are presented in Table 2.

An association was identified between the practice of PA and gender. The male participants were 2.7 times more likely to engage in physical activity $(\mathrm{p}=$ 0.036). There was no association between such practice and knowledge of free programs or household income ( $\mathrm{p}=0.411$ and $\mathrm{p}=0.746$, respectively).

The set of activities inherent to the routines of students was structured as: academic and work or household and leisure. With regard to leisure, three groups of elements were identified, physical sporting activities (engagement in physical activities), sedentary behavior (activities related to low energy expenditure), and sociocultural activities (participation in parties, artistic or religious events and/or social meetings). The interactions with colleagues, friends, and family were emphasized by students, as well as the use of electronic devices (Figure 1).

According to Figure 1, household activities were the least mentioned by the students, and among leisure activities, the physical sporting ones had less importance in the accounts of students. The excerpts below illustrate such activities. 
Table 1. Participants' sociodemographic profiles $(\mathrm{n}=141)$. São Paulo, Brazil.

\begin{tabular}{|c|c|}
\hline Characteristics & $\mathrm{n}(\%)$ \\
\hline \multicolumn{2}{|l|}{ Age } \\
\hline 18 to 20 years old & $75(53.6)$ \\
\hline 23 to 27 years old & $65(46.4)$ \\
\hline Not informed & $1(0.7)$ \\
\hline \multicolumn{2}{|l|}{ Race } \\
\hline White & $112(79.4)$ \\
\hline Black or mixed-race & $29(20.6)$ \\
\hline \multicolumn{2}{|l|}{ Household Income } \\
\hline Up to $2 \mathrm{MW}^{*}$ & $41(30.1)$ \\
\hline 2 to $5 \mathrm{MW}^{\star}$ & $48(35.3)$ \\
\hline Over $5 \mathrm{MW}^{*}$ & $47(34.3)$ \\
\hline Not informed & $5(3.5)$ \\
\hline \multicolumn{2}{|l|}{ Gender } \\
\hline Female & $124(87.9)$ \\
\hline Male & $16(11.3)$ \\
\hline Not informed & $1(0.7)$ \\
\hline \multicolumn{2}{|l|}{ Marital status } \\
\hline No partner & $136(96.5)$ \\
\hline With partner & $5(3.5)$ \\
\hline
\end{tabular}

$\mathrm{MW}^{\star}$ : Minimum wage at the time of data collection: $\mathrm{R} \$ 724.00$.

Table 2. Students who reported practicing physical activities $(n=62)$. São Paulo, Brazil.

\begin{tabular}{cc}
\hline \multicolumn{1}{c}{ Physical activity } & $\mathrm{n}(\%)$ \\
\hline Frequency & $18(29.0)$ \\
Once a week & $34(54.8)$ \\
Two or three times a week & $10(16.1)$ \\
Four times a week or more & \\
Modality & $38(61.3)$ \\
Individual (running, walking, weight training) & $24(38.7)$ \\
Group (sports, group classes) & $34(54.8)$ \\
Know of free programs & $27(43.5)$ \\
Yes & $1(1.6)$ \\
No & $18(29.0)$ \\
Not informed & $43(69.4)$ \\
Participants in free PA programs & $1(1.6)$ \\
Yes & \\
No &
\end{tabular}




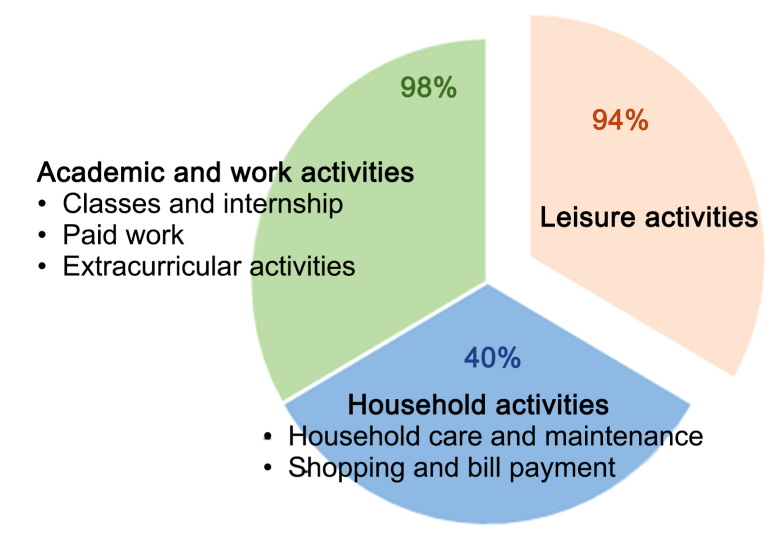

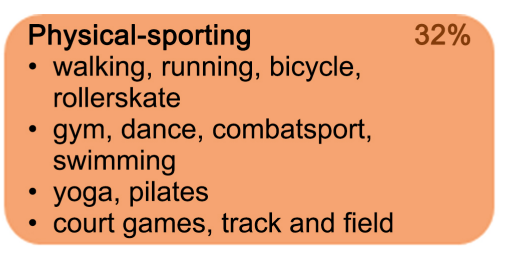

\section{Walking}

Gym

Sociocultural activities $\quad 89 \%$

- bars, restaurants, parties and

nightclubs

- being with family, friends, partner

- shopping, movies, theater, church

- parks, clubs, trips

Sedentary behavior

- esthetic and personal care

- sleep, rest and stay at home

- reading, listening to music, cooking

- videogame, internet and tv

\section{$53 \%$}

Computer

Cell phone
Friends

Church

Parents

Figure 1. Synthesis of results of the open question about students' routines ( $\mathrm{n}=141)$. São Paulo, Brazil.

I basically wake up at 6 am go to the gym on Mondays and Wednesdays and play volleyball on Fridays; (...) (EST 123). On weekends, I have lunch with my family, and in the afternoon, I go to the gym (EST 29). Sporadically, I do Pilates, play futsal and go running (EST 59). I go walking at the end of the afternoon for an hour with my mother (EST 40).

Concerning sedentary behavior, sleeping in, rest, reading books, and esthetic care were mentioned by the participants.

... On the weekends, I usually take care of myself, do the nails, hair, etc. I try to relax and rest (EST 93). On the weekends, I sleep a lot (...) (EST 09). On the weekends, I sleep until 11:30 am (EST 17).

The use of technological resources and means of communication were also part of the students' set of activities; they emphasized the use of video games, smartphones, computers, television, and the Internet.

I have good family communication through the Internet and cell phones (EST 93).... at the end of the afternoon, I go back to student housing where I spend the evening watching TV (series, news, studying, or using the computer or Internet) (EST 135). I wake up, play video games (...) (EST 68). ...leisure activities (TV, the Internet, music...) (EST 03). (...) When I go back home, I use the computer (EST 67).

Regarding sociocultural activities, gatherings, dinners, meetings and visits to family and friends were described by the participants, as well as going to shopping malls, bars and university parties.

On the weekends, I go back to my family's home. On the weekends, I spend time with my mother and grandmother and help my sister with her homework... (EST 80). I usually spend the weekend at my mother's home (my 
parents are separated). I try to spend the morning with her and always cook different meals (EST 94). I travel to my hometown, visit my friends, go to bars, nightclubs, shopping malls and restaurants (EST 119). We usually go out for Japanese food, house parties and nightclubs (EST 20).

The participants also mentioned, in their routine, engaging in religious, artistic and cultural activities.

I use my time for craftwork with my mother (...) (EST 135). On Sundays, we wake up at 8 am and go to the evangelical church in my city where we teach at the Sunday school (...) (EST 02). I take drama classes and go to the movies (EST 33).

\section{Discussion}

From the analysis of the study's results it was observed that, even though academic, household, and work activities were important in the students' weekly routine, they organize their time so they can enjoy leisure time with different types of activities.

The organization of time among occupations, daily chores and entertaining and relaxing activities is a potential resource to be explored related to students' health and well-being, since the lack of leisure may trigger personal and professional damage, as well as physical and physic overload [15] [16] [19].

With regard to leisure possibilities, although $43.9 \%$ of students had mentioned different sporting practices and types, it was observed that such activities were not priority among the university students studied because they were in the third place in the set of activities mentioned in the open question. This result suggests that engaging in and maintaining PA is a matter that still needs to be strengthened in this context. In general, regular and low levels of PA in leisure time were found in other studies conducted with university students [9] [12].

Literature also reports that, usually, male students present more active behavior patterns than female [9] [12] corroborating with the findings of this study. Such aspect should be taken into consideration, since this study's sample was, mainly, composed of female students, suggesting that this population may be more attracted by less active leisure possibilities. This panorama shows the need for implementation of alternatives and strategies that encourage physical-sporting practices in the academic environment and the creation of spaces that foster the discussion of these themes among university students, especially in the female population, aiming to identify the obstacles and facilitators for more active behavior.

Besides being driven by specific interest, motivation and personal preferences issues, engagement in PA in leisure time may be also related to economical and time management issues. Nevertheless, there was no association between PA in leisure time and household income of the population studied, suggesting that time becomes the main influence in this specific population. In this sense, the 
development of future studies that investigate if, in fact, time management is a decisive factor for PA in leisure time for this population are recommended.

Academic requirements and even a double day (study and work) result in short periods for access and move around in parks and other environments with more active leisure possibilities, so that students tend to look for other more immediate alternatives of entertainment.

This study's results show that the majority of students, although engaging in several sociocultural programs, dedicated part of their leisure time for behavior and habits related to sedentary lifestyle, corroborating with other studies [4] [5] [6] [9] [12].

In this sense, activities such as watching $\mathrm{TV}$, listening to music, staying at home, and using the internet were listed by the students as part of their leisure time also corroborating with previous studies conducted in different countries [5] [6] [20] [22]. The use of electronic devices such as computers and smartphones were widely mentioned by participants and, in fact provide convenience allowing real-time social interaction, as well as access to books, music, social networks, online movies in several environments [5] [6] [20] [22].

Thus, the several facets of technological resources characterize them as a leisure activity for those with short time available. This option stands out due to easy access and the possibility of using them during class breaks, in the bus journey, and even simultaneously with other activities. In this sense, it is not possible to disregard the use benefits of these resources, however, the indiscriminate use both in terms of time spent and the context may lead to weakening of non-virtual interactions, interference in daily life activities and resulting in negative impact in health and even in the academic performance of students [23]. Thus, the use of these resources may also be a challenge regarding leisure possibilities and engaging in more active behavior, especially for the young population.

With regard to sociocultural activities, it was noted that dinners, visits and outings were highlighted by the students and are opportunities for rest and entertainment also accessible for those who do not have much free time, and may strengthen or widen support networks.

Thus, given that social support is one of the most important strategies for coping with stress [14], considering the moments of interaction as an essential element of these individuals' academic life may be critical for the development and implementation of more sensitive and decisive preventive strategies and health promotion actions.

Moreover, religious and cultural activities were also described as part of the students' routine, emphasizing the potential of such activities in awakening feelings of appreciation in the individual, strengthening emotional and social aspects and "humanizing", in a certain way, these undergraduate students' routine. In addition, these activities may contribute to widen the students' sense of purpose and creativity.

Attending parties and nightclubs and going to bar was also mentioned in the 
list of students' activities and, even though they are characterized as entertainment and relaxing activities, they may also be risk factors for the adoption of less healthy lifestyles such as substance consumption, fewer hours of sleep and dedication to academic activities [24] [25] [26].

Thus, from the results of this study it is recommend the promotion of playful moments, cultural events and facilitation of physical spaces for interaction and leisure in the academic environment. Moreover, encourage and stimulate students to engage in more active leisure options by hosting sports events and promoting places and programs of physical activity available in the region are also actions that may favor less sedentary behavior and broaden de alternatives for alcohol and other drugs consumption induced by stress.

Regarding technological resources, it is suggested to increase the discussions about their benefits and risks, as well as, promote participative forums to list the guidelines about the good use of such devices in the academic environment.

\section{Cultural Considerations}

Previous studies have shown that deep knowledge of sociocultural context, concept and interpretation of leisure by subjects, and the motivations for choosing specific activities are decisive aspects for the development and implementation of culturally sensitive leisure and entertainment strategies. The encouragement to creativity, strengthening of personal relations, and potential to relaxation are essential aspects to be considered. Thus, this study's results contribute to increase the debate and guide practices in this sense.

Thus, it is important point out that the Brazilian perception about the free programs and services tend to be associated with low quality or as directed to people with lower incomes. It could explain the low percent-age of students that did not use the free programs available, including those at the university campus in the study.

Considering that the majority of students mentioned esthetic and personal care activities, we consider that this can also reflect some cultural influence, because Brazilian people are highly worried about physical appearance. Brazil is the country with the second highest demand for plastic surgery [27] and has the third highest rate of beauty product consumption in the world [28].

Despite of the video game, internet, and TV overuse can be a problem, it is important to highlight that, in our country, public mental health services are not officially structured to receive people with technological addiction as other countries. As a result, we do not have official data related to the prevalence of this addiction.

A high percentage of students mentioned staying with family during the weekends, even those whose parents live in other cities, with some of them being very distant from the university campus studied. This aspect also expressed cultural traces from Brazilians and people from Latin America that tend to maintain strong links with extended family, even after having jobs or their own families. 


\section{Conclusions}

The opportunities and engagement in leisure activities are important components for the promotion and maintenance of the population's health and wellbeing. In the university context, such actions are strategic for coping with stressful situations experienced in the academic daily life. Thus, the objective of this study was to identify the practice of PA and other leisure possibilities in the nursing students' routine.

It was identified that studies dedicated time in their routine to enjoy leisure moments engaging in sociocultural activities and other low energy expenditure activities. A reduced part of the participants mentioned the practice of PA. Male students presented to be more likely to engage in such activities. From this panorama, it is recommended the development of strategies that stimulate more active behavior and reduce sedentary lifestyle behavior in leisure time with the promotion of sports events in the academic setting.

Other possibilities are the implementation of playful and cultural activities that strengthen interpersonal relations and provide relaxing moments in the university environment, reducing exposure and moving around in events and activities that increase exposure to the consumption of substances, excessive use of technological resources and other risk behavior.

The main cultural aspects emphasized from our results were aspects related to not using free programs, the strong family connection amongst participants, and the possible influence of the esthetic appeal from Brazilian culture.

In short, it is appreciated that this investigation contributes to the debate and development of actions aiming to broaden leisure options sensitive to the students' reality and possible of being inserted in their university daily life and setting, aiming at the improvement of their mental and physical health as well as to aid indirectly in their professional training and promotion of a healthier school environment.

As a study limitation, it is highlighted the sample by convenience and data collection in only one university course, which limits generalization of results. However, the study brings relevant elements to foster the theme discussion in different learning environments and recommendations of aspects inherent to students' mental health and well-being considering culture-related specificities.

\section{Acknowledgements}

Research Support Program of the University of São Paulo.

\section{Conflicts of Interest}

The authors declare that there they have no conflicts of interest associated with this study.

\section{References}

[1] Nunes, M.F.O. and Hutz, C.S. (2014) Analysis of Scientific Papers about Leisure: A 
Review. Psicologia: Teoria e Pesquisa, 30, 307-315. https://doi.org/10.1590/S0102-37722014000300008

[2] Gomes, C.L. (2014) Recreation and Leisure in Current Latin American Societies. Polis (Santiago, Enlínea), 13, 363-384. https://doi.org/10.4067/S0718-65682014000100020

[3] Newman, D.B., Tay, L. and Diener, E. (2014) Leisure and Subjective Well-Being: A Model of Psychological Mechanisms as Mediating Factors. Journal of Happiness Studies, 15, 555-578. https://doi.org/10.1007/s10902-013-9435-X

[4] Bichescu, A. (2014) Leisure Time Sport Activities of the Students at Resita University. Procedia-Social and Behavioral Sciences, 117, 735-740. https://doi.org/10.1016/j.sbspro.2014.02.291

[5] Eratay, E. and Aydoğan, Y. (2015) Study of the Relationship between Leisure Time Activities and Assertiveness Levels of Students of Abant Izzet Baysal University. Procedia-Social and Behavioral Sciences, 191, 2213-2218. https://doi.org/10.1016/j.sbspro.2015.04.532

[6] Honari, H., Goudarzi, M. and Heidari, A. (2010) An Investigation of the Ways Tehran University Students Follow a Specific Life Style and Pass Their Leisure Time with an Emphasis on Sport. Procedia-Social and Behavioral Sciences, 2, 5498-501. https://doi.org/10.1016/j.sbspro.2010.03.896

[7] Nunes, M.F.O., Pires, J.G., Azevedo, M.C. and Hutz, C.S. (2014) Satisfaction and Autonomy in Leisure Activities among College Students. Psicologia: Teoria e Prática, 16, 91-103. https://doi.org/10.15348/1980-6906/psicologia.v16n1p91-103

[8] Silva, A.O. and Neto, C.J.L. (2014) Association between Levels of Physical Activity and Common Mental Disorder in University Students. Motricidade, 10, 49-59. https://doi.org/10.6063/motricidade.10(1).2125

[9] Júnior, C.E.F., Barreto, L.A., Oliveira, J.A.A., Almeida, P.C. and Leite, J.A.D. (2012) Evaluation of the Level of Physical Activity and Associated Factors in Medical Students from Fortaleza CE. Revista Brasileira de Ciências do Esporte, 34, 955-967. https://doi.org/10.1590/S0101-32892012000400011

[10] Al-Eisa, E., Buragadda, S. and Melam, G.R. (2014) Association between Physical Activity and Psychological Status among Saudi Female Students. BMC Psychiatry, 14, 238. https://doi.org/10.1186/s12888-014-0238-3

[11] Gerber, M., Brand, S., Herrmann, C., Colledge, F., Holsboer-Trachsler, E. and Puhse, U. (2014) Increased Objectively Assessed Vigorous-Intensity Exercise Is Associated with Reduced Stress, Increased Mental Health and Good Objective and Subjective Sleep in Young Adults. Physiology \& Behavior, 135, 17-24. https://doi.org/10.1016/j.physbeh.2014.05.047

[12] Pires, C.G.S., Mussi, F.C., Cerqueira, B.B., Pitanga, F.J.G. and Silva, D.O. (2013) Physical Activity Practice among Undergraduate Students in Nursing. Acta Paulista de Enfermagem, 26, 436-443. https://doi.org/10.1590/S0103-21002013000500006

[13] Agyar, E. (2013) Life Satisfaction, Perceived Freedom in Leisure and Self-Esteem: The Case of Physical Education and Sport Students. Procedia-Social and Behavioral Sciences, 93, 2186-2193. https://doi.org/10.1016/j.sbspro.2013.10.185

[14] Tercan, E. (2015) An Examination of Leisure Participation, Family Assessment and Life Satisfaction in University Students. Procedia-Social and Behavioral Sciences, 186, 58-63. https://doi.org/10.1016/j.sbspro.2015.04.123

[15] Hirsch, C.D., Barlem, E.L.D., Tomaschewski-Barlem, J.G., Lunardi, V.L. and Oliveira, A.C.C. (2015) Predictors of Stress and Coping Strategies Adopted by Nursing Students. Acta Paulista de Enfermagem, 28, 224-229. 
https://doi.org/10.1590/1982-0194201500038

[16] Bampi, L.N.S., Baraldi, S., Guilhem, D., Pompeu, R.B. and Campos, A.C.O. (2013) Nursing Undergraduate Students' Perception of Quality of Life. Revista Gaúcha de Enfermagem, 34, 125-132. https://doi.org/10.1590/S1983-14472013000200016

[17] Lima, J.R.N., Pereira, A.K.A.M., Nascimento, E.G.C. and Alchieri, J.C. (2013) Perceptions of Nursing Students about the Process of Health/Illness during Graduation. Saúde \& Transformação Social, 4, 54-62.

[18] Esperidião, E., Barbosa, J.A., Silva, N.S. and Munari, D.B. (2013) The Mental Health of Nursing Students: An Integrative Review of Literature. SMAD Revista Eletrônica Saúde Mental Álcool e Drogas, 9, 144-153. https://doi.org/10.11606/issn.1806-6976.v9i3p144-153

[19] Tomaschewski-Barlem, J.G., Lunardi, V.L., Ramos, A.M., Silveira, R.S., Barlem, E.L.D. and Ernandes, C.M. (2013) Signs and Symptoms of the Burnout Syndrome among Undergraduate Nursing Students. Textocontextoenferm, 22, 754-762. https://doi.org/10.1590/S0104-07072013000300023

[20] Janković, B., Nikolić, M., Vukonjanski, J. and Terek, E. (2016) The Impact of Facebook and Smart Phone Usage on the Leisure Activities and College Adjustment of Students in Serbia. Computers in Human Behavior, 55, 354-363. https://doi.org/10.1016/j.chb.2015.09.022

[21] Baldissera, V.D.A., Jaques, A.E., Philbert, L.A.S., Corral-Mulato, S., Santos, J.L. and Bueno, S.M.V. (2011) The Perceptions of Nursing Academics on Leisure. Cogitare Enfermagem, 16, 326-332. https://doi.org/10.5380/ce.v16i2.20635

[22] Li, J., Lepp, A. and Barkley, J.E. (2015) Locus of Control and Cell Phone Use: Implications for Sleep Quality, Academic Performance, and Subjective Well-Being. Computers in Human Behavior, 52, 450-457. https://doi.org/10.1016/j.chb.2015.06.021

[23] Samaha, M. and Hawi, N.S. (2016) Relationships among Smartphone Addiction, Stress, Academic Performance, and Satisfaction with Life. Computers in Human Behavior, 57, 321-325. https://doi.org/10.1016/j.chb.2015.12.045

[24] Dambrowski, K., Sakae, T.M. and Remor, K.V.T. (2017) Prevalence of Psychoactive Substances Use in Students of Health Area Courses at a Private University of Southern Brazil. Arquivos Catarinenses de Medicina, 46, 140-153.

[25] Zeferino, M.T., Hamilton, H., Brands, B., Wright, M.G.M., Cumsille, F. and Khenti, A. (2015) Drug Consumption among University Students: Family, Spirituality and Entertainment Moderating Influence of Pairs. Texto \& Contexto-Enfermagem, 24, 125-135.

[26] Pillon, S.C., O’Brien, B. and Piedra, K.A.C. (2005) The Relationship between Drugs Use and Risk Behaviors in Brazilian University Students. Revista Latino-Americana de Enfermagem, 13, 1169-1176. https://doi.org/10.1590/S0104-11692005000800011

[27] Heidekrueger, P.I., Juran, S., Ehrl, D., Aung, T., Tanna, N. and Broer, P.N. (2017) Global Aesthetic Surgery Statistics: A Closer Look. Journal of Plastic Surgery and Hand Surgery, 51, 270-274. https://doi.org/10.1080/2000656X.2016.1248842

[28] Associação Brasileira da Indústria de Higiene Pessoal, Perfumaria e Cosméticos (ABIHPEC) (2015) III Caderno de Tendências. Higiene Pessoal, Perfumaria e Cosméticos. BB editora, São Paulo. 